\title{
Contribution of large genomic BRCA1 alterations to early-onset breast cancer selected for family history and tumour morphology: a report from The Breast Cancer Family Registry
}

Letitia D Smith', Andrea A Tesoriero ${ }^{1,2}$, Ee M Wong ${ }^{1}$, Susan J Ramus ${ }^{3}$, Frances P O'Malley ${ }^{4,5}$, Anna Marie Mulligan ${ }^{5,6}$, Mary Beth Terry ${ }^{7}$, Ruby T Senie ${ }^{7}$, Regina M Santella ${ }^{8}$, Esther M John9, Irene L Andrulis ${ }^{4,5,10}$, Hilmi Ozcelik ${ }^{5}$, Mary B Daly ${ }^{11}$, Andrew K Godwin ${ }^{11,17}$, Saundra S Buys ${ }^{12}$, Stephen Fox ${ }^{13}$, David E Goldgar ${ }^{14}$, Graham G Giles ${ }^{15}$, John L Hopper ${ }^{16}$, Melissa C Southey ${ }^{1 *}$

\begin{abstract}
Introduction: Selecting women affected with breast cancer who are most likely to carry a germline mutation in BRCA1 and applying the most appropriate test methodology remains challenging for cancer genetics services. We sought to test the value of selecting women for BRCA1 mutation testing on the basis of family history and/or breast tumour morphology criteria as well as the value of testing for large genomic alterations in BRCA1.

Methods: We studied women participating in the Breast Cancer Family Registry (BCFR), recruited via populationbased sampling, who had been diagnosed with breast cancer before the age of 40 years who had a strong family history of breast or ovarian cancer $(n=187)$ and/or a first primary breast tumour with morphological features consistent with carrying a BRCA1 germline mutation ( $n=133 ; 37$ met both criteria). An additional 184 women diagnosed before the age of 40 years who had a strong family history of breast or ovarian cancer and who were not known to carry a germline BRCA1 mutation were selected from among women who had been recruited into the BCFR from clinical genetics services. These 467 women had been screened for BRCA1 germline mutations, and we expanded this testing to include a screen for large genomic BRCA1 alterations using Multiplex Ligationdependent Probe Amplification.
\end{abstract}

Results: Twelve large genomic BRCA1 alterations were identified, including 10 (4\%) of the 283 women selected from among the population-based sample. In total, 18 (12\%), 18 (19\%) and $16(43 \%)$ BRCA1 mutations were identified in the population-based groups selected on the basis of family history only ( $n=150)$, the group selected on the basis of tumour morphology only $(n=96)$ and meeting both criteria $(n=37)$, respectively.

Conclusions: Large genomic alterations accounted for 19\% of all BRCA1 mutations identified. This study emphasises the value of combining information about family history, age at diagnosis and tumour morphology when selecting women for germline BRCA1 mutation testing as well as including a screen for large genomic alterations.

\footnotetext{
* Correspondence: msouthey@unimelb.edu.au

${ }^{1}$ Genetic Epidemiology Laboratory, Department of Pathology, University of

Melbourne, Melbourne, Victoria 3010, Australia

Full list of author information is available at the end of the article
} 


\section{Introduction}

For many women with a personal and/or family history of breast cancer, knowing that they carry a germline mutation in a breast cancer predisposition gene can be informative for their clinical management and that of family members. However, mutations in currently known breast cancer predisposition genes are very rare, and the majority of women who undergo genetic testing for these genes are not found to be carriers of mutations (identifiable by current molecular methods).

It remains challenging but necessary for clinical genetics services, and in some settings, insurers, to select women most likely to carry a germline mutation in $B R C A 1$ and BRCA2 for genetic testing. Most tools used for estimating a woman's risk of carrying a mutation in one of these genes are predominantly based on family history. Even when accurately reported, well collected and verified, family history is often not predictive of carrier status unless it is extreme, as family history is not highly sensitive or specific to mutation status [1]. Recent and current work have incorporated some details of the associated breast cancer pathology into risk models, but this effort has essentially been restricted to immunohistochemical data such as estrogen receptor (ER), progesterone receptor (PR), HER2 and cytokeratin (CK5/6, CK14) status [2-4].

It has been widely reported that some breast tumour morphological features are associated with carrying a $B R C A 1$ mutation and that consideration of a few of these features can identify almost all $B R C A 1$ germline mutation carriers among women with early-onset breast cancer without taking into account family history [5-7].

The methodological approaches applied to identify BRCA1 mutations also vary between clinical service laboratories and can have an impact on the proportion of women identified as carrying a mutation [8]. Most currently applied methods are based on polymerase chain reaction (PCR) assays and have moderate to high specificity and sensitivity for identifying mutations involving one or a few nucleotides within defined, predominantly exonic regions. Analytical methods for interpreting these nucleotide alterations are continuing to improve $[9,10]$. However, short-fragment, PCR-based analyses are usually insensitive to the detection of large genomic alterations, and unless these specific tests are applied such mutations are likely to be missed in a routine short-fragment PCR-based screening protocol.

The frequency of large genomic alterations varies between populations, and this has become more apparent as methods to detect such mutations have become more robust and available [11]. Ticha et al. [12] reported that $12.3 \%$ of all BRCA1 mutations identified in the Czech population are large genomic rearrangements. Similarly, Agata et al. [13] reported that they could represent up to one-third of $B R C A 1$ mutations identified in the Italian population. Reports from the Netherlands have demonstrated that these types of mutations can account for $27 \%$ to $36 \%$ of all BRCA1 mutations in the Dutch population $[14,15]$. In addition to the effect of founder mutations, some regions of $B R C A 1$ seem to be implicated more frequently in genomic alterations, such as the exon $1 \mathrm{~A}-2$ region [16]. The value of large genomic rearrangement testing for many clinical genetics services remains unclear.

We sought to further investigate the value of using family history and tumour morphologic features in selecting women for BRCA1 mutation testing. We applied two criteria (one for family history and one for tumour morphological features) to select women participating in the Breast Cancer Family Registry (BCFR) who had already undergone extensive BRCA1 mutation screening [17]. This testing had not, however, included routine testing for large genomic alterations in the $B R C A 1$ region, so we applied Multiplex Ligation-dependent Probe Amplification (MLPA; MRC-Holland, Amsterdam, the Netherlands) testing to determine the proportion of BRCA1 mutations in the selected women that could be attributed to mutations of this type.

\section{Materials and methods}

\section{The Breast Cancer Family Registry}

The BCFR was established in 1995 as an international collaborative resource to facilitate research into the genetic and environmental causes of breast cancer. The BCFR has collected detailed epidemiological data, family history information and biospecimens from over 13,000 families [18]. Relevant to this study are the incidence of breast cancer cases and their relatives ascertained through population-based cancer registries (populationbased case families) and families with strong cancer histories of breast or ovarian cancer identified through cancer family clinics and community outreach (clinicbased families). Population-based families were recruited in the San Francisco Bay Area, northern California, USA; the Province of Ontario, Canada; and Melbourne and Sydney, Australia. Clinic-based families were recruited in Philadelphia, New York City and Utah, USA; the Province of Ontario, Canada; and Melbourne and Sydney, Australia. A proband is defined as the index case (identified from the relevant cancer registry) in populationbased families and as the youngest affected participating female member of clinic-based families. All sites used standardised questionnaires and protocols to collect family history information, epidemiological and clinical data, and biological specimens, with a strong emphasis on quality control measures throughout the collection, processing and storing of data and samples $[17,18]$. This study was approved by the Human Research Ethics Committee of The University of Melbourne. 


\section{$B R C A 1$ and $B R C A 2$ mutation testing}

BCFR participants have undergone extensive testing for $B R C A 1$ and BRCA2 mutations using techniques described previously $[8,17,19]$, including two-dimensional gel scanning, denaturing high-performance liquid chromatography, enzymatic mutation detection, single-strand conformation polymorphism analysis and the protein truncation test. Direct gene sequencing of both genes has also been carried out by individual laboratories and Myriad Genetics (Salt Lake City, UT, USA) $[8,17,19]$. Mutation testing in other genes, such as ATM, TP53 and $C H E K 2$, has also been performed and reported elsewhere [20-22]. The criteria used by the BCFR for defining deleterious mutations are the same as those used by the Breast Cancer Information Core [23] and Myriad Genetics. No screening was applied that specifically tested for large genomic alterations in the $B R C A 1$ gene. Some carriers of $B R C A 1$ duplication exon 13 were identified by specific PCR-based testing for the breakpoints $[19,24]$ and via RNA-based protein truncation testing [8].

\section{Selection criteria}

\section{Women recruited through population-based sampling}

Family history criteria We selected case probands who were diagnosed with breast cancer before age 40 years and had two or more first- or second-degree relatives with breast or ovarian cancer.

Tumour morphology criteria We selected case probands whose tumour morphology was consistent with carrying a BRCA1 mutation [7]. Case probands from the Australian BCFR were selected if their breast tumours had five or more of the following morphological features: (1) mitotic index $>50 / 10$ high-power fields (HPF), (2) malignant nuclear grade, (3) little or no tubule formation, (4) a trabecular growth pattern, (5) pushing margins (>50\%), (6) a circumscribed growth pattern, (7) a syncytial growth pattern, (8) necrosis and (9) moderate or intense lymphocytic infiltrate [5,7]. From the Northern California BCFR, we first selected all breast cancers that had been scored as medullary or atypical medullary as their primary or secondary histological type and then reviewed the histological slides of these cases to identify those that met the criteria described above [7]. From the Ontario BCFR, we selected cases that had five or more of the following features: (1) mitotic index $>50 / 10 \mathrm{HPF},(2)$ malignant nuclear grade, (3) little or no tubule formation, (4) a syncytial growth pattern, (5) circumscribed borders, (6) a moderate intense lymphocytic infiltrate and (7) necrosis. The selection of case probands from population-based registries was done without regard to their known BRCA1 or BRCA2 mutation status.

\section{Women enrolled through clinic-based recruitment}

We selected the youngest affected member of clinicbased families for this study if they had been diagnosed with breast cancer before age 40 years and had two or more first- or second-degree relatives with breast and/or ovarian cancer. Probands were excluded if they were already known to carry a $B R C A 1$ or $B R C A 2$ deleterious mutation.

\section{BRCA1 large genomic alteration testing by Multiplex Ligation-dependent Probe Amplification}

Testing for large genomic alterations was performed by MLPA using the SALSA MLPA Kit P002B BRCA1 (MRC-Holland) as described by Schouten et al. [25]. Quantities of 50 to $100 \mathrm{ng}$ per reaction of DNA extracted from Guthrie card blood spots, peripheral whole blood or a lymphoblastoid cell line were used. All reactions were performed in duplicate on a Corbett Palm-Cycler, Corbett Life Science, Mortlake, NSW, Australia, and PCR fragments were analysed on an ABI 3730 DNA Analyser (Applied Biosystems, Foster City, CA, USA).

Analysis of the fragment peak areas and visual examination of the MLPA histograms were performed to identify large genomic alterations [26]. A normalised value of 1.0 represents the detection of both exonic alleles (that is, no alteration), a value $\leq 0.65$ is the threshold suggestive of loss of one exonic allele (that is, deletion) and a value $\geq 1.3$ suggests the gain of one or more exonic alleles (that is, duplication). All cases with normalised values $\leq 0.65$ or $\geq 1.3$ were repeated in an independent molecular analysis. Large alterations were verified using the SALSA MLPA Kit P087 BRCA1 (MRC-Holland). For P087 analysis, cases were compared with BRCA1 mutation-negative controls. Cases that had MLPA analysis suggestive of a single exon loss or gain were sequenced to confirm that probe hybridization was not being disrupted by genetic variation in the MLPA probe hybridization regions.

\section{Results}

\section{Screening of the population-based probands}

Two hundred eighty-three probands from populationbased families were selected for this study. Of these probands, 150 met the family history only criteria, 96 met the tumour morphology only criteria and 37 fulfilled both criteria. BRCA1 and BRCA2 mutation testing had already identified $15 B R C A 1$ mutation carriers in the family history only group (15 of 150 , or $10 \%$ ), 14 $B R C A 1$ mutation carriers in the morphology only group (14 of 96 , or $15 \%$ ) and 12 BRCA1 mutation carriers in the group who met both criteria (12 of 37 , or $32 \%$ ). There were 17 BRCA2 mutation carriers who had been identified in the family history only group (17 of 150 , or $11 \%)$, one BRCA2 mutation carrier in the morphology only group (1 of 96 , or $1 \%$ ) and four met both criteria (4 of 37 , or $11 \%$ ) (see Table 1 ). 
Table 1 Women recruited into BCFRs on the basis of population-based sampling who met the family history and tumour morphology criteria of this study ${ }^{a}$

\begin{tabular}{|c|c|c|c|c|c|c|}
\hline $\begin{array}{l}\text { Mutation } \\
\text { status of } \\
\text { proband }\end{array}$ & $\begin{array}{l}\text { Family history } \\
\text { only, } 44 / 53 / 53^{b} \\
(n=150)\end{array}$ & $\begin{array}{l}\text { Family historyc, } \\
63 / 57 / 67^{b} \\
(n=187)\end{array}$ & $\begin{array}{l}\text { Tumour } \\
\text { morphology only, } \\
80 / 14 / 2^{b}(n=96)\end{array}$ & $\begin{array}{l}\text { Tumour } \\
\text { morphology }^{d}, 99 / \\
18 / 16^{b}(n=133)\end{array}$ & $\begin{array}{l}\text { Both family history and } \\
\text { tumour morphology, 19/4/ } \\
14^{b}(n=37)\end{array}$ & $\begin{array}{l}\text { Study total, } \\
143 / 71 / 69^{b} \\
(n=283)\end{array}$ \\
\hline $\begin{array}{l}\text { No identified } \\
\text { mutation, } n\end{array}$ & 110 & 127 & 77 & 94 & 17 & 204 \\
\hline $\begin{array}{l}\text { Identified } \\
\text { mutation, n }\end{array}$ & 40 & 60 & 19 & 39 & 20 & 79 \\
\hline \multirow{2}{*}{$\begin{array}{l}\text { BRCA1 } \\
\text { LGA, n }\end{array}$} & 3 & 7 & 3 & 7 & 4 & 10 \\
\hline & $1 / 1 / 1^{b}$ & $3 / 3 / 1^{b}$ & $3 / 0 / 0^{b}$ & $5 / 2 / 0^{b}$ & $2 / 2 / 0^{b}$ & $6 / 3 / 1^{b}$ \\
\hline \multirow{2}{*}{$\begin{array}{l}\text { Other } \\
\text { BRCA1 } \\
\text { mutation, } \\
n\end{array}$} & 15 & 27 & $15^{e}$ & $27^{e}$ & 12 & 42 \\
\hline & $1 / 8 / 6^{b}$ & $8 / 9 / 10^{b}$ & $14 / 1 / 0^{b}$ & $21 / 2 / 4^{b}$ & $7 / 1 / 4^{b}$ & $22 / 10 / 10^{b}$ \\
\hline $\begin{array}{l}\text { BRCA2 } \\
\text { mutation, } \\
n\end{array}$ & 17 & 21 & 1 & 5 & 4 & 22 \\
\hline $\begin{array}{l}\text { ATM, } \\
\text { CHEK2, } \\
\text { TP53 } \\
\text { mutations, } \\
n\end{array}$ & 5 & 5 & 0 & 0 & 0 & 5 \\
\hline $\begin{array}{l}\text { BRCA1 } \\
\text { mutations, \% }\end{array}$ & 12 & 18 & 19 & 26 & 43 & 18 \\
\hline BRCA1 LGA, \% & 17 & 21 & 17 & 21 & 25 & 19 \\
\hline
\end{tabular}

${ }^{a}$ BCFR, Breast Cancer Family Registry; LGA, large genomic alteration; ATM, ataxia telangiectasia mutated gene; CHEK2, CHK2 checkpoint homolog gene; TP53, tumour protein 53 gene; ${ }^{b}$ data divided by BCFR (Australia/northern California/Ontario BCFRs); 'including women who also met the tumour morphology criteria;

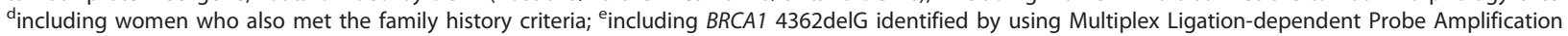
during this study.

Table 1 shows that MLPA analysis identified eight case probands as carriers of large BRCA1 genomic alterations. Two additional case probands were known to have a BRCA1 exon 13 duplication that had been identified by previous testing, and these are included in Table 1. The BRCA1 large genomic alterations included five single-exon deletions (exon 5, exon 17 and exon 20) or duplications (exon 13) and five alterations involving the deletion of multiple exons (exon 1A-2, exon 1A-17, exon 1A-23 and exon 1A-24). An additional proband was found to have an MLPA profile consistent with an exon 13 deletion. However, Sanger sequencing of the exon revealed a 1-bp deletion adjacent to the ligation site of the P002 exon 13 probes. This mutation was characterised as BRCA1 4362delG and is reported in the "Other BRCA1 mutation" row in Table 1. The detection of this mutation had been missed by prior two-dimensional gel electrophoresis testing.

By combining the data from the screen for large genomic alterations with the mutation information that had been generated prior to this study using routine screening methods [17], we identified 18 probands (12\%) in the family history only group carrying a deleterious $B R C A 1$ mutation (3 probands, $2 \%$ carried large genomic alterations), 18 probands (19\%) in the tumour morphology only group carrying a BRCA1 mutation (3 probands, $3 \%$ carried large genomic alterations) and 16 probands (43\%) in the group meeting both criteria and carrying a BRCA1 mutation (4 probands, $11 \%$ carried large genomic alterations) (Table 1). Overall, 10 (19\%) of the 52 BRCA1 mutations found in these women were large genomic alterations.

As there were some differences in the methods used to select cases that qualified for inclusion in the morphology group across the population-based BCFRs (see Materials and methods), the outcomes of the BRCA1 testing are detailed both as overall findings and for each BCFR individually (population-based samples) in Table 1.

\section{Screening of probands recruited from clinical services}

There were 184 case probands from the BCFR clinic recruitment participants that met our study criteria (excluding BRCA1 and BRCA2 mutation-carrying probands). MLPA screening identified a BRCA1 exon 22 deletion (reported previously) and a BRCA1 exons 14-20 deletion. Histological sections stained with haematoxylin and eosin were available for review from the breast cancer carrying the BRCA1 exon 22 deletion, and this section was found to meet the tumour morphology criteria applied to the population-based probands in this study (Table 2). 
Table 2 Details of BRCA1 large genomic alterations identified in this study

\begin{tabular}{|c|c|c|c|c|c|}
\hline Sample & Selection criteria $(n)$ & $\begin{array}{l}\text { Large genomic } B R C A 1 \\
\text { alteration }\end{array}$ & $\begin{array}{l}\text { Proband age at breast } \\
\text { cancer diagnosis, yr }\end{array}$ & $\begin{array}{l}\text { Tumour } \\
\text { morphology } \\
\text { score }^{\mathrm{a}}\end{array}$ & $\begin{array}{l}\text { Family history } \\
\text { (age at diagnosis, yr) }\end{array}$ \\
\hline \multirow{26}{*}{$\begin{array}{l}\text { Population- } \\
\text { based }\end{array}$} & Family history (150) & Deletion exon 5 & 38 and 44 & 3 & Breast, sister (42) \\
\hline & & & & & Ovarian, paternal aunt (44) \\
\hline & & & & & $\begin{array}{l}\text { Ovarian, paternal } \\
\text { grandmother }(60)\end{array}$ \\
\hline & & Deletion exon 1A-24 & 39 and 49 & 3 & Breast, sister (53) \\
\hline & & & & & Ovarian, sister (40) \\
\hline & & & & & Ovarian, sister (50) \\
\hline & & Duplication exon $13^{\mathrm{b}}$ & 39 and 39 & 3 & Breast, sister (33) \\
\hline & & & & & Breast, mother (49) \\
\hline & & & & & $\begin{array}{l}\text { Breast, maternal } \\
\text { grandmother (62) }\end{array}$ \\
\hline & & & & & $\begin{array}{l}\text { Breast, paternal } \\
\text { grandmother (49) }\end{array}$ \\
\hline & Tumour morphology (96) & Deletion exon 20 & 31 and 35 & 7 & $\begin{array}{l}\text { Breast, paternal } \\
\text { grandmother (n.d.) }\end{array}$ \\
\hline & & Deletion exon $1 \mathrm{~A}-23^{\mathrm{C}}$ & 33 & 5 & Breast, paternal aunt (71) \\
\hline & & Duplication exon $13^{b}$ & 36 & 9 & Breast, mother (50) \\
\hline & & & & & Ovarian, mother (68) \\
\hline & & & & & Ovarian, paternal aunt (55) \\
\hline & $\begin{array}{l}\text { Family history and tumour } \\
\text { morphology (37) }\end{array}$ & Deletion exon 17 & 31 & 7 & Breast, maternal aunt (34) \\
\hline & & & & & Ovarian, maternal aunt (35) \\
\hline & & Deletion exon $1 \mathrm{~A}-2^{\mathrm{C}}$ & 29 & 7 & Breast, maternal aunt (30) \\
\hline & & & & & Breast, paternal aunt (52) \\
\hline & & & & & Ovarian, mother (56) \\
\hline & & Deletion exon 1A-17 & 36 and 38 & 8 & Breast, mother (53) \\
\hline & & & & & Ovarian, mother (62) \\
\hline & & & & & $\begin{array}{l}\text { Breast, maternal } \\
\text { grandmother (84) }\end{array}$ \\
\hline & & & & & $\begin{array}{l}\text { Ovarian, maternal } \\
\text { grandmother (n.d.) }\end{array}$ \\
\hline & & Deletion exon 1A-23 & 34 & 7 & Breast, mother (28) \\
\hline & & & & & $\begin{array}{l}\text { Breast, maternal } \\
\text { grandmother ( } 45)\end{array}$ \\
\hline \multirow[t]{5}{*}{ Clinic-based } & Family history (184) & Deletion exon 22 & 35 & 7 & $\begin{array}{l}\text { Breast, paternal aunt ( } 23 \\
\text { and 24) }\end{array}$ \\
\hline & & & & & Ovarian, paternal aunt (49) \\
\hline & & Deletion exons $14-20$ & 36 & n.d. & Breast, sister (35) \\
\hline & & & & & Breast, mother (43) \\
\hline & & & & & $\begin{array}{l}\text { Ovarian, maternal } \\
\text { grandmother (n.d.) }\end{array}$ \\
\hline Total & 467 & 12 & & & \\
\hline
\end{tabular}

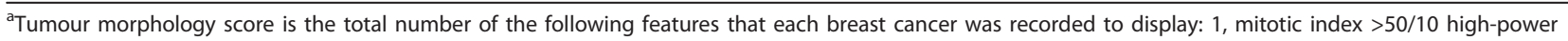
fields; 2, malignant nuclear grade; 3, little or no tubule formation; 4, a trabecular growth pattern; 5, pushing margins ( $>50 \%$ ); 6 , circumscribed growth pattern; 7 , a syncytial growth pattern; 8 , necrosis; and 9, moderate or intense lymphocytic infiltrate; ${ }^{b} B R C A 1$ exon 13 duplications were identified prior to this study; 'described by Smith et al. [26]; n.d., age at diagnosis unknown (no data).

Table 2 shows the age at breast cancer diagnosis, the details of the tumour morphology and the family history details of the young women found to carry a large genomic alteration in BRCA1 from both the populationbased and clinic-recruited families participating in the BCFR. All 12 large genomic alterations in BRCA1 reported in this study were verified using the P087 MLPA Kit.

\section{Discussion}

Knowing that a woman with breast cancer carries a germline BRCA1 mutation informs her clinical 
management and that of her relatives. However, it remains challenging for clinical genetics services to select the women most likely to carry a germline mutation in $B R C A 1$ for genetic testing. Most tools used for estimating a woman's probability of carrying a BRCA1 mutation have been based predominantly on family history. Even when accurately reported, well-collected and verified, is often unhelpful, except when the history is extreme. That is family history is not highly sensitive or specific to $B R C A 1$ mutation status.

We have investigated the relative strengths of using family history and tumour morphology, as well as both criteria together, to select the women with early onset breast cancer most likely to carry $B R C A 1$ mutations (including large genomic alterations) by using the BCFR [18]. This resource provided many strengths for the study: (1) it provided a large sample size, with 467 women meeting one or more of the study criteria; (2) significant germline mutation testing had already been performed for $B R C A 1$ and BRCA2 [17] using validated methods [8]; (3) family history of breast or ovarian cancer had been collected from each case proband using a standardised, validated instrument (ensuring higher-quality data than would likely have been collected from a similar number of women in a clinical setting) [18]; and (4) tumour morphology had been reviewed for a proportion of the breast cancers using a standardised, validated review form $[7,27]$.

Prior to this study, 149 case probands (4\%) who had been recruited into the BCFR via population-based sampling had been found to carry a BRCA1 mutation [17]. This is consistent with the frequencies reported in other studies utilising this and similar population-based samplings [28-30].

Using family history data collected in a standardised fashion by the BCFR, we identified 187 women recruited via population-based sampling who had a family history at least as strong as two first- or second-degree relatives with breast or ovarian cancer. Genetic testing of these women identified $60(32 \%)$ with a mutation in a breast cancer susceptibility gene, $34(18 \%)$ in BRCA1.

Using tumour morphology data collected by a standard pathology review of many of the breast cancers arising in women participating in the Australian and Ontario BCFRs, and by performing an extended review of the medullary and atypical medullary type breast cancers in the northern California BCFR (see Materials and methods), we identified 133 women whose tumour morphology met our selection criteria and thus had many of the morphological features consistent with being a BRCA1 mutation carrier. Of these, 39 (29\%) have now been found to carry a germline mutation in a breast cancer susceptibility gene, $34(26 \%)$ in BRCA1.
The women who met both criteria composed the group most enriched for BRCA1 mutation carriers (43\%). The proportion of large genomic alterations in the total number of mutations identified was also slightly higher in the women who met both the family history and tumour morphology criteria (25\%) compared with the proportion in women who met only one of these criteria (both 20\%).

Similar work involving large genomic alterations in $B R C A 2$ could also be beneficial, but it is likely to have less impact given current data which suggests there is a broader morphological phenotype of breast cancers carrying these mutations and the extreme rarity of these mutations in BRCA2 [31].

\section{Conclusions}

These results highlight the value of incorporating information on family history and tumour morphology when selecting women with the highest chance of carrying a mutation in BRCA1 for mutation testing. This study also shows that testing for large genomic alterations is of value in this setting because 10 (19\%) of the 52 mutation carriers indentified in the groups of women selected for this study carried large genomic alterations that were identifiable by using MLPA.

\section{Abbreviations}

BCFR: Breast Cancer Family Registry; MLPA: Multiplex Ligation-dependent Probe Amplification.

\section{Acknowledgements}

This work was supported by the National Cancer Institute, National Institutes of Health, under RFA-CA-06-503 and through cooperative agreements with members of the Breast Cancer Family Registry (BCFR) and Principal Investigators, including Cancer Care Ontario (grant U01 CA69467), Columbia University (grant U01 CA69398), Fox Chase Cancer Center (grant U01 CA69631), Huntsman Cancer Institute (grant U01 CA69446), Northern California Cancer Center (grant U01 CA69417), University of Melbourne (grant U01 CA69638) and Research Triangle Institute Informatics Support Center (RFP N02PC45022-46). The content of this article does not necessarily reflect the views or policies of the National Cancer Institute or any of the collaborating BCFR centers, nor does the mention of trade names, commercial products or organizations imply endorsement by the U.S. government or the BCFR. JLH is a National Health and Medical Research (NHMRC) Australia Fellow and Victorian Breast Cancer Consortium Group Leader, and MCS is a NHMRC Senior Research Fellow and Victorian Breast Cancer Consortium Group Leader. Multiplex Ligation-dependent Probe Amplification fragments were analysed by the Australian Genome Research Facility (AGRF), Melbourne, Australia. AGRF is funded by the Commonwealth of Australia.

\section{Author details}

${ }^{1}$ Genetic Epidemiology Laboratory, Department of Pathology, University of Melbourne, Melbourne, Victoria 3010, Australia. ${ }^{2}$ QIAGEN Pty. Ltd., Doncaster, Victoria 3108, Australia. ${ }^{3}$ Gynaecological Cancer Research Laboratory, Institute for Women's Health, University College London, 74 Huntley Street, London, WC1E 6AU, UK. ${ }^{4}$ Department of Pathology and Laboratory Medicine, Mt Sinai Hospital, 600 University Avenue, Toronto, ON, M5G 1X5, Canada. ${ }^{5}$ Department of Pathobiology and Laboratory Medicine, University of Toronto, 1 King's College Circle, Toronto, ON, M5S 1A8, Canada. 'St Michael's Hospital, 30 Bond Street, Toronto, ON, M5B 1W8, Canada. ${ }^{7}$ Department of Epidemiology, Mailman School of Public Health, Columbia University, 722 
West 168th Street, New York, NY 10032, USA. ${ }^{8}$ Department of Environmental Health Sciences, Mailman School of Public Health, Columbia University, 722 West 168th Street, New York, NY 10032, USA. ${ }^{9}$ Department of Epidemiology, Cancer Prevention Institute of California, 2201 Walnut Avenue, Fremont, CA 94538, USA. ${ }^{10}$ Samuel Lunenfeld Research Institute, Mount Sinai Hospital, Department of Molecular Genetics, University of Toronto, Ontario Cancer Genetics Network, Cancer Care Ontario, 620 University Avenue, Toronto, ON, M5G 2C1, Canada. ${ }^{11}$ Fox Chase Cancer Center, 333 Cottman Avenue, Philadelphia, PA 19111-2497, USA. ${ }^{12}$ Huntsman Cancer Institute, University of Utah Health Sciences Center, Salt Lake City, UT 84112, USA. ${ }^{13}$ Department of Pathology, Peter MacCallum Cancer Center, St Andrew's Place, East Melbourne, Victoria 3002, Australia. ${ }^{14}$ Department of Dermatology, University of Utah School of Medicine, Salt Lake City, UT 84112, USA. ${ }^{15}$ Cancer Epidemiology Centre, The Cancer Council Victoria, Rathdowne Street, Carlton 3052, Australia. ${ }^{16} \mathrm{Centre}$ for Molecular, Environmental, Genetic and Analytic Epidemiology, University of Melbourne, Melbourne, Victoria 3010, Australia. ${ }^{17}$ Department of Pathology and Laboratory Medicine, University of Kansas Medical Center, 3901 Rainbow Blvd, Kansas City, KS 66160, USA.

\section{Authors' contributions}

LDS, AAT and EMW conducted molecular analyses and contributed to data interpretation and manuscript preparation. SJR and $\mathrm{HO}$ contributed expert molecular assistance and contributed to the manuscript preparation. FPO, SF and AMM contributed morphological data and pathology expertise and contributed to the manuscript preparation. MBT, RTS, RMS, EMJ, ILA, MBD, AKG, SSB, DEG, GGG and JLH contributed data and DNA from participants of the BCFR and contributed to the manuscript preparation. MCS led this study, including its conception and design, acquisition of data and biospecimens, analysis, interpretation of data and preparation of the manuscript.

\section{Competing interests}

The authors declare that they have no competing interests.

Received: 27 September 2010 Revised: 30 November 2010

Accepted: 31 January 2011 Published: 31 January 2011

\section{References}

1. Antoniou AC, Cunningham AP, Peto J, Evans DG, Lalloo F, Narod SA, Risch HA, Eyfjord JE, Hopper JL, Southey MC, Olsson H, Johannsson O, Borg A, Pasini B, Radice P, Manoukian S, Eccles DM, Tang N, Olah E, Anton-Culver H, Warner E, Lubinski J, Gronwald J, Gorski B, Tryggvadottir L, Syrjakoski K, Kallioniemi OP, Eerola H, Nevanlinna H, Pharoah PD, et al: The BOADICEA model of genetic susceptibility to breast and ovarian cancers: updates and extensions. Br J Cancer 2008, 98:1457-1466.

2. Lakhani S, van de Vijver MJ, Jacquemier J, Anderson TJ, Osin PP, McGuffog L, Easton DF, for the Breast Cancer Linkage Consortium: The pathology of familial breast cancer: predictive value of immunohistochemical markers estrogen receptor, progesterone receptor, HER-2, and $\mathrm{p} 53$ in patients with mutations in BRCA1 and BRCA2. J Clin Oncol 2002, 20:2310-2318.

3. James PA, Doherty R, Harris M, Mukesh BN, Milner A, Young MA, Scott C: Optimal selection of individuals for BRCA mutation testing: a comparison of available methods. J Clin Oncol 2006, 24:707-715.

4. Mavaddat N, Rebbeck TR, Lakhani SR, Easton DF, Antoniou AC: Incorporating tumour pathology information into breast cancer risk prediction algorithms. Breast Cancer Res 2010, 12:R28.

5. Armes JE, Egan AJM, Southey MC, Dite GS, McCredie MRE, Giles GG, Hopper JL, Venter DJ: The histologic phenotypes of breast carcinoma occurring before age 40 years in women with and without BRCA1 and BRCA2 germline mutations: a population-based study. Cancer 1998, 83:2335-2345.

6. Lakhani S, Jacquemier J, Sloane JP, Gusterson BA, Anderson TJ, van de Vijver MJ, Farid LM, Venter D, Antoniou A, Storfer-Isser A, Smyth E, Steel CM, Haites N, Scott RJ, Goldgar D, Neuhausen S, Daly PA, Ormiston W, McManus R, Scherneck S, Ponder BA, Ford D, Peto J, Stoppa-Lyonnet D, Bignon YJ, Struewing JP, Spurr NK, Bishop DT, Klijn JG, Devilee P, et al: Multifactorial analysis of differences between sporadic breast cancers and cancers involving BRCA1 and BRCA2 mutations. J Natl Cancer Inst 1998, 90:1138-45.

7. Southey MC, Ramus SJ, Dowty JG, Smith LD, Tesoriero AA, Wong EE, Dite GS, Jenkins MA, Byrnes GB, Winship I, Phillips KA, Giles GG, Hopper JL:
Morphological predictors of BRCA1 germline mutations in young women with breast cancer. $\mathrm{Br} J$ Cancer 2011.

8. Andrulis IL, Anton-Culver H, Beck J, Bove B, Boyd J, Buys S, Goodwin AK, Hopper JL, Li F, Neuhausen SL, Ozcelik H, Peel D, Santella RM, Southey MC, van Orsouw NJ, Venter DJ, Vijg J, Whittemore AS: Comparison of DNAand RNA-based methods for detection of truncating BRCA1 mutations. Hum Mutat 2002, 20:65-73.

9. Tavtigian SV, Byrnes GB, Goldgar DE, Thomas A: Classification of rare missense substitutions, using risk surfaces, with genetic- and molecularepidemiology applications. Hum Mutat 2008, 29:1342-1354.

10. Tavtigian SV, Greenblatt MS, Lesueur F, Byrnes GB, IARC Unclassified Genetic Variants Working Group: In silico analysis of missense substitutions using sequence-alignment based methods. Hum Mutat 2008, 29:1327-1336.

11. Sluiter MD, van Rensburg EJ: Large genomic rearrangements of the $B R C A 1$ and $B R C A 2$ genes: review of the literature and report of a novel BRCA1 mutation. Breast Cancer Res Treat 2011, 125:325-349.

12. Ticha I, Kleibl Z, Stribrna J, Kotlas J, Zimovjanova M, Mateju M, Zikan M, Pohlreich P: Screening for genomic rearrangements in BRCA1 and BRCA2 genes in Czech high-risk breast/ovarian cancer patients: high proportion of population specific alterations in BRCA1 gene. Breast Cancer Res Treat 2010, 124:337-347.

13. Agata S, Viel A, Della Puppa L, Cortesi L, Fersini G, Callegaro M, Dalla Palma M, Dolcetti R, Federico M, Venuta S, Miolo G, D'Andrea E, Montagna M: Prevalence of BRCA1 genomic rearrangements in a large cohort of Italian breast and breast/ovarian cancer families without detectable BRCA1 and BRCA2 point mutations. Genes Chromosomes Cancer 2006, 45:791-797.

14. Petrij-Bosch A, Peelen T, van Vliet M, van Eijk R, Olmer R, Drüsedau M, Hogervorst FB, Hageman S, Arts PJ, Ligtenberg MJ, Meijers-Heijboer $\mathrm{H}_{\text {, }}$ Klijn JG, Vasen HF, Cornelisse CJ, van't Veer L, Bakker E, van Ommen GJ, Devilee P: BRCA1 genomic deletions are major founder mutations in Dutch breast cancer patients. Nat Genet 1997, 17:341-345.

15. Hogervorst FB, Nederlof PM, Gille JJ, McElgunn CJ, Grippeling M, Pruntel R, Regnerus R, van Welsem T, van Spaendonk R, Menko FH, Kluijt I, Dommering C, Verhoef S, Schouten JP, van't Veer LJ, Pals G: Large genomic deletions and duplications in the BRCA1 gene identified by a novel quantitative method. Cancer Res 2003, 63:1449-1453.

16. Van den Ouweland AM, Dinjens WN, Dorssers LC, van VeghelPlandsoen MM, Brüggenwirth HT, Withagen-Hermans CJ, Collée JM, Joosse SA, Terlouw-Kromosoeto JN, Nederlof PM: Deletion of exons 1a-2 of BRCA1: a rather frequent pathogenic abnormality. Genet Test $\mathrm{Mol}$ Biomarkers 2009, 13:399-406.

17. Neuhausen SL, Ozcelik H, Southey MC, John EM, Godwin AK, Chung W, Iriondo-Perez J, Miron A, Santella RM, Whittemore A, Andrulis IL, Buys SS, Daly MB, Hopper JL, Seminara D, Senie RT, Terry MB, Breast Cancer Family Registry: BRCA1 and BRCA2 mutation carriers in the Breast Cancer Family Registry: an open resource for collaborative research. Breast Cancer Res Treat 2009, 116:379-386.

18. John EM, Hopper JL, Beck JC, Knight JA, Neuhausen SL, Senie RT, Ziogas A, Andrulis IL, Anton-Culver H, Boyd N, Buys SS, Daly MB, O'Malley FP, Santella RM, Southey MC, Venne VL, Venter DJ, West DW, Whittemore AS, Seminara D, Breast Cancer Family Registry: The Breast Cancer Family Registry: an infrastructure for cooperative multinational, interdisciplinary and translational studies of the genetic epidemiology of breast cancer. Breast Cancer Res 2004, 6:R375-R389.

19. Dite GS, Jenkins MA, Southey MC, Hocking JS, Giles GG, McCredie MR, Venter DJ, Hopper JL: Familial risks, early-onset breast cancer, and BRCA1 and BRCA2 germline mutations. J Natl Cancer Inst 2003, 95:448-457.

20. Chenevix-Trench G, Spurdle AB, Gatei M, Kelly H, Marsh A, Chen X, Donn K, Cummings M, Nyholt D, Jenkins MA, Scott C, Pupo GM, Dörk T, Bendix R, Kirk J, Tucker K, McCredie MR, Hopper JL, Sambrook J, Mann GJ, Khanna KK: Dominant negative ATM mutations in breast cancer families. J Natl Cancer Inst 2002, 94:205-215.

21. Bernstein JL, Teraoka S, Southey MC, Jenkins MA, Andrulis IL, Knight JA, John EM, Lapinski R, Wolitzer AL, Whittemore AS, West D, Seminara D, Olson ER, Spurdle AB, Chenevix-Trench G, Giles GG, Hopper IL, Concannon P: Population-based estimates of breast cancer risks associated with ATM gene variants c.7271T $>\mathrm{G}$ and c.1066-6T>G (IVS10$6 \mathrm{~T}>\mathrm{G})$ from the Breast Cancer Family Registry. Hum Mutat 2006, 27:1122-1128. 
22. Mouchawar J, Korch C, Byers T, Pitts TM, Li E, McCredie MR, Giles GG, Hopper UL, Southey MC: Population-based estimate of the contribution of TP53 mutations to subgroups of early-onset breast cancer: Australian Breast Cancer Family Study. Cancer Res 2010, 70:4795-4800.

23. Breast Cancer Information Core. [http://research.nhgri.nih.gov/bic/]

24. Leong T, Whitty J, Keilar M, Mifsud S, Ramsay J, Birrell G, Venter D, Southey M, McKay M: Mutation analysis of BRCA1 and BRCA2 cancer predisposition genes in radiation hypersensitive cancer patients. Int $J$ Radiat Oncol Biol Phys 2000, 48:959-965.

25. Schouten JP, McElgunn CJ, Waaijer R, Zwijnenburg D, Diepvens F, Pals G: Relative quantification of 40 nucleic acid sequences by multiplex ligation-dependent probe amplification. Nucleic Acids Res 2002, 30:e57.

26. Smith LD, Tesoriero AA, Ramus SJ, Dite G, Royce SG, Giles GG,

McCredie MRE, Hopper JL, Southey MC: BRCA1 promoter deletions in young women with breast cancer and a strong family history: a population-based study. Eur J Cancer 2007, 43:823-827.

27. Longacre TA, Ennis M, Quenneville LA, Bane AL, Bleiweiss IJ, Carter BA, Catelano E, Hendrickson MR, Hibshoosh H, Layfield LJ, Memeo L, Wu H, O'Malley FP: Interobserver agreement and reproducibility in classification of invasive breast carcinoma: an $\mathrm{NCl}$ breast cancer family registry study. Mod Pathol 2006, 19:195-207.

28. Southey MC, Tesoriero AA, Andersen CR, Jennings KM, Brown SM, Dite GS, Jenkins MA, Osborne RH, Maskiell JA, Porter L, Giles GG, McCredie MR, Hopper JL, Venter DJ: BRCA1 mutations and other sequence variants in a population based sample of Australian women with breast cancer. $\mathrm{Br} J$ Cancer 1999, 79:34-39.

29. Hopper JL, Southey MC, Dite GS, Jolley DJ, Giles GG, McCredie MR, Easton DF, Venter DJ, Australian Breast Cancer Family Study: Populationbased estimate of the average age-specific cumulative risk of breast cancer for a defined set of protein-truncating mutations in BRCA1 and BRCA2. Cancer Epidemiol Biomarkers Prev 1999, 8:741-747.

30. Ozcelik H, Knight JA, Glendon G, Yazici H, Carson N, Ainsworth PJ, Taylor SA, Feilotter H, Carter RF, Boyd NF, Andrulis IL, Ontario Cancer Genetics Network: Individual and family characteristics associated with protein truncating $B R C A 1$ and $B R C A 2$ mutations in an Ontario population based series from the Cooperative Family for Breast Cancer Studies. J Med Genet 2003, 40:e91.

31. Agata S, Dalla Palma M, Callegaro M, Scaini MC, Menin C, Ghiotto C, Nicoletto O, Zavagno G, Chieco-Bianchi L, D'Andrea E, Montagna M: Large genomic deletions inactivate the $B R C A 2$ gene in breast cancer families. J Med Genet 2005, 42:e64.

doi:10.1186/bcr2822

Cite this article as: Smith et al: Contribution of large genomic BRCA1 alterations to early-onset breast cancer selected for family history and tumour morphology: a report from The Breast Cancer Family Registry. Breast Cancer Research 2011 13:R14.

\section{Submit your next manuscript to BioMed Central and take full advantage of:}

- Convenient online submission

- Thorough peer review

- No space constraints or color figure charges

- Immediate publication on acceptance

- Inclusion in PubMed, CAS, Scopus and Google Scholar

- Research which is freely available for redistribution

Submit your manuscript at www.biomedcentral.com/submit
Biomed Central 